\title{
Evaluation of Tomato (Solanum lycopersicum L.) Genotypes under Water Stress Based on Yield and Physiological Parameters
}

\author{
Namitha Elizabeth $^{1 *}$, Beena Thomas $^{2}$ and N. Thouseem ${ }^{3}$ \\ Department of Plant Breeding and Genetics, College of agriculture, Vellayani, \\ Kerala Agricultural University-695522, Kerala, India \\ *Corresponding author
}

\section{A B S T R A C T}

\section{Keywords \\ Tomato, Water stress, Relative water content, Proline content, Stomatal frequency, Genetic parameters.}

Article Info

Accepted:

04 December 2017

Available Online:

10 January 2018
Of all the abiotic stresses limiting crop productivity, drought is considered as the most important. Despite various research initiatives, drought continues to be a major challenge. To overcome this limitation and to improve crop productivity, it is important to improve the drought tolerance associated traits in cultivated plants. Twenty genotypes of tomato were evaluated in a Randomized Block Design (RBD) at the Department of Plant breeding and Genetics, College of Agriculture, Vellayani, during 2015-2017 to identify high yielding genotypes of tomato under water stress condition. Analysis of variance showed that significant variation was present in the germplasm for the characters studied. Accession A6 (Kottayam local) was identified superior in yield performance under water stress. The accession A6 (Kottayam local) also recorded the highest relative water content, stomatal frequency and proline content. Accumulation of proline in leaves was found to be an important water stress tolerance mechanism.

\section{Introduction}

Tomato (Solanum lycopersicum L.) is one of the most accepted and extensively cultivated vegetables in the world.It is a self-pollinated solanaceous vegetable crop originated in the Peru-Ecuador-Bolivia region (Rick, 1969).Being a rich source of vitamins and minerals, tomato is a highly popular vegetable. India is the second largest producer of tomato accounting for $10.58 \%$ of the world's production (FAO, 2011). The production in India is $16.38 \mathrm{mt}$ from an area of 0.7 mha with a productivity of $21 \mathrm{t} \mathrm{ha}^{-1}$ in 2014-2015 (NHB, 2016).
Abiotic stress is the primary cause of crop loss worldwide, causing average yield losses of more than 50\% for major crops (Boyer, 1982). Of all the abioitic stresses limiting crop productivity, drought is considered as the most important one and many efforts have been made to improve crop productivity under water-limiting conditions (Cattivelli et al., 2008). In many parts around the world, drought is considered as a major constraint that affects plant growth and development. Despite of many decades of research drought continues to be a major challenge due to its unpredictable occurrence, timing, severity and duration. To overcome this limitation and to 
improve crop productivity, it is important to improve the drought tolerance associated traits in cultivated plants. For sustaining global food production, drought tolerant crops with consistent yield under extensive periods of mild or severe stress are essential. Hence, the genotypes identified as adaptive in target areas will be useful to be introduced in breeding programs.

\section{Materials and Methods}

Twenty genotypes of tomato were evaluated in a Randomized Block Design (RBD) at the Department of Plant breeding and Genetics, College of Agriculture, Vellayani, during 2015-2017 with the objective of identifying high yielding genotypes of tomato under water stress condition.Seedlings were raised in protrays. One month old seedlings were transplanted to the main field. The seedlings were planted at a spacing of $60 \mathrm{~cm} \times 60 \mathrm{~cm}$. All the cultural practices were undertaken timely as per the Package of Practices Recommendations of Kerala Agricultural University (KAU, 2011). Water stress was imposed from flowering onwards by restricting the irrigation to once in three days at $10 \mathrm{~mm}$ depth.

The genotypes were evaluated for following traits viz., plant height $(\mathrm{cm})$, number of primary branches plant ${ }^{-1}$, number of leaves plant $^{-1}$, days to $50 \%$ flowering, number of fruits cluster ${ }^{-1}$, number of fruits plant ${ }^{-1}$, fruit length $(\mathrm{cm})$, fruit girth $(\mathrm{cm})$, fruit volume $\left(\mathrm{cm}^{3}\right)$, fruit weight $(\mathrm{g})$, yield $\operatorname{plant}^{-1}(\mathrm{~g})$, stomatal frequency, relative water content $(\%)$, canopy temperature $\left({ }^{0} \mathrm{C}\right)$ and proline content of leaves $\left(\mu \mathrm{mol} \mathrm{g}^{-1}\right)$.All the observations were taken 60 DAT. Canopy temperature measurements were taken using an infrared thermometer.

Relative leaf water content was estimated using the formula,
RWC $=($ Fresh weight - Dry weight $) /($ Turgid weight - Dry weight) X 100.

Proline content was estimated as per the procedure given by Bates et al., (1973). Leaf samples were homogenized in $10 \mathrm{ml}$ of $3 \%$ sulpho salicylic acid. After centrifuging at 3,000 rpm for $10 \mathrm{~min}$, equal volume of glacial acetic acid and acid ninhydrin solutions were added to the extract. The samples were heated to $100{ }^{0} \mathrm{C}$ for $1 \mathrm{~h}$ and $4 \mathrm{ml}$ of toluene was added. The absorbance of the toluene layer was measured at $520 \mathrm{~nm}$. The quantity of proline was calculated using standard curve.

The data on various parameters were analysed statisticallyas per methods suggested by Panse and Sukhatme (1985) for analysis of variance, Burton (1952) for variability, Johnson et al., (1955) for heritability and genetic advance in per cent of mean.

\section{Results and Discussion}

The twenty genotypes showed significant difference in their performance under water stress conditions. The mean performances of the genotypes for the characters under study were evaluated (Table 1).

Analysis of variance revealed significant differences among the genotypes for all the 15 traits studied indicating presence of significant variability in the germplasm that could be exploited through selection. Similar results were noticed in tomato by Cheema and Singh (2005), Basavaraj et al., (2010) and Dar and Sharma (2011).

Yield per plant showed the greatest range of variation as reported by Haydar et al., (2007), Mehta and Asati (2008), Ghosh et al., (2010), and Kaushik et al., (2011), followed by proline content, number of fruits per plant, stomatal frequency, fruit volume and number of leaves per plant (Table 2). 
Among the genotypes, Plant height was the highest for accession A19 $(77.00 \mathrm{~cm})$, which was on par with other accessions likeA8(75.00 $\mathrm{cm}), \mathrm{A} 10(74.33 \mathrm{~cm})$, accession A1 $(73.33 \mathrm{~cm})$, A15(73.00 cm), A7(71.33 cm), A14(71.00 $\mathrm{cm}), \mathrm{A} 17(70.67 \mathrm{~cm}), \mathrm{A} 3(70.33 \mathrm{~cm}), \mathrm{A} 2$ $(68.67 \mathrm{~cm})$ and A9 $(68.33 \mathrm{~cm})$. Least plant height was observed for A16 $(52.67 \mathrm{~cm})$ which was on par with A18 $(60.00 \mathrm{~cm})$.

The number of primary branches varied from 6.00 (accession A1) to 2.33 (A7). The accession A1 showed the highest number of leaves (45.00). The lowest number of leaves was observed in A15 (19.00). Accession A3 registered the longest days to $50 \%$ flowering (67.00). The duration for days to $50 \%$ flowering was the least in A2 (52.00). The number of fruits cluster $^{-1}$ was the maximum for accession A14 (4.33). The accession A9 had the lowest number of fruits cluster ${ }^{-1}$ i.e. 2.67 .

Number of fruits plant ${ }^{-1}$ was observed maximum in accession A6 (19.90). The lowest number of fruits plant ${ }^{-1}$ was recorded in A10 (4.60). The length of the fruit was the highest for the accession A7 $(4.37 \mathrm{~cm})$. The least fruit length was recorded in the accession A1 (3.00 $\mathrm{cm})$. The highest average fruit girth was recorded for the accession A18 $(14.47 \mathrm{~cm})$

The least fruit length was recorded in the accession A15 $(10.23 \mathrm{~cm})$ and the highest fruit volume was recorded for the accession A14 $\left(29.33 \mathrm{~cm}^{-3}\right)$. Fruit volume was least for the accession A1 $\left(11.00 \mathrm{~cm}^{-3}\right)$. The accession A14 had the highest fruit weight $(45.66 \mathrm{~g})$. The accession A1 had the lowest fruit weight $(23.00 \mathrm{~g})$.

The highest yield plant $^{-1}(603.67 \mathrm{~g})$ was recorded in accession A6. The least fruit weight was observed in accession A1 $(102.63 \mathrm{~g})$. Stomatal frequency ranged from $166.67 \mathrm{~cm}^{-2}$ (A10) to $743.33 \mathrm{~cm}^{-2}$ (A6). The accession A6 showed the highest relative leaf water content $(78.95 \%)$. RWC was the lowest for the accession A9 (52.67\%). The highest canopy temperature was recorded for the accession A2 $\left(36.57^{0} \mathrm{C}\right)$. The lowest canopy temperature was recorded for the accession A9 $\left(31.17^{0} \mathrm{C}\right)$. The proline content of the leaves ranged from $6.03 \mu \mathrm{mol} \mathrm{g}{ }^{-1}$ (A13) to 57.72 $\mu \mathrm{mol} \mathrm{g}^{-1}$ (A6). A6 was on par with the accessions A4 $\left(56.97 \mu \mathrm{mol} \mathrm{g}^{-1}\right)$ and A2 (55.12 $\left.\mathrm{mol} \mathrm{g}^{-1}\right)$ (Fig. 2 and 3).

\section{Genetic parameters}

The variability present in the germplasm was then estimated using genetic parameters such as genotypic coefficient of variation (PCV), phenotypic coefficient of variation (GCV), environmental coefficient of variation (ECV), heritability in broad sense $\left(\mathrm{H}^{2}{ }_{\mathrm{b}}\right)$ and genetic advance as percent of mean to understand the nature of variation present (Table 3).

\section{Genotypic coefficient of variation}

The value of genotypic coefficient of variation (GCV) ranged from 5.86 for canopy temperature to 66.02 for proline content of leaves. High GCV was observed for proline content of leaves (66.02), yield per plant (45.58), fruits per plant (42.93), stomatal frequency (36.14), fruit volume (30.00), number of leaves per plant (22.45) and number of primary branches per plant (22.45). Characters like fruit weight (15.81) and number of fruits per cluster (12.04) showed moderate genotypic coefficient of variation.

Low GCV was observed for relative water content (9.70), fruit length (8.97), days to $50 \%$ flowering (7.36), plant height (6.94), fruit girth (6.79) and canopy temperature (5.86). Narolia et al., (2012) and Kaushik et al., (2011) have also reported similar findings for plant height, average fruit weight and number of branches. 
Int.J.Curr.Microbiol.App.Sci (2018) 7(1): 214-225

Table.1 List of genotypes

\begin{tabular}{|c|c|c|}
\hline Sl.No & Name of the Genotype & Source \\
\hline 1 & Nellanadu local & Local collection \\
\hline 2 & Kuttichal local I & Local collection \\
\hline 3 & Venpalavattam local & Local collection \\
\hline 4 & Palakkad local & Local collection \\
\hline 5 & Vellayani local I & Local collection \\
\hline 6 & Kottayam local & Local collection \\
\hline 7 & Kuttichal local II & Local collection \\
\hline 8 & Kaithamukku local & Local collection \\
\hline 9 & Pettah local & Local collection \\
\hline 10 & Vellayani local II & Local collection \\
\hline 11 & Haripad local & Local collection \\
\hline 12 & ArkaAlok & IIHR, Bangalore \\
\hline 13 & Thrissur local & Local collection \\
\hline 14 & ArkaVikas & IIHR, Bangalore \\
\hline 15 & ArkaSaurabh & IIHR, Bangalore \\
\hline 16 & ArkaMeghali & IIHR, Bangalore \\
\hline 17 & Vellayani Vijay & KAU \\
\hline 18 & Anagha & $\mathrm{KAU}$ \\
\hline 19 & Akshay & KAU \\
\hline 20 & Manulekshmi & KAU \\
\hline
\end{tabular}


Table.2 Mean performance of twenty genotypes for different characters

\begin{tabular}{|c|c|c|c|c|c|c|c|c|c|c|c|c|c|c|c|c|}
\hline $\begin{array}{c}\text { Access } \\
\text { ion } \\
\text { No. }\end{array}$ & $\begin{array}{l}\text { Name of the } \\
\text { accession }\end{array}$ & $\mathrm{X} 1$ & $\mathbf{X} 2$ & $\mathbf{X 3}$ & $\mathrm{X} 4$ & $\mathbf{X 5}$ & $\mathbf{X 6}$ & X7 & $\mathbf{X 8}$ & $\mathbf{X 9}$ & $\mathbf{X 1 0}$ & X11 & $\mathbf{X 1 2}$ & $\mathbf{X 1 3}$ & X14 & $\mathbf{X 1 5}$ \\
\hline A1 & Nellanadu Local & 73.33 & 6.00 & 45.00 & 58.00 & 3.67 & 10.67 & 3.00 & 10.30 & 11.00 & 23.00 & 102.63 & 257.67 & 71.88 & 28.67 & 11.65 \\
\hline A2 & Kuttichal Local I & 68.67 & 3.67 & 30.67 & 52.00 & 3.33 & 15.10 & 4.00 & 11.60 & 22.67 & 28.35 & 420.17 & 636.33 & 77.00 & 31.77 & 55.12 \\
\hline A3 & $\begin{array}{c}\text { Venpalavattam } \\
\text { Local }\end{array}$ & 70.33 & 4.00 & 39.33 & 67.00 & 4.00 & 8.03 & 3.63 & 12.60 & 18.67 & 32.45 & 262.00 & 347.33 & 68.35 & 29.90 & 20.78 \\
\hline A4 & Palakkad Local & 64.33 & 3.67 & 34.00 & 53.67 & 4.33 & 11.13 & 3.80 & 11.77 & 16.33 & 36.11 & 402.33 & 518.67 & 75.67 & 34.73 & 56.97 \\
\hline A5 & Vellayani Local I & 64.67 & 3.00 & 30.00 & 62.33 & 4.33 & 10.17 & 3.87 & 11.90 & 16.33 & 30.73 & 347.33 & 458.00 & 70.45 & 33.07 & 6.33 \\
\hline A6 & Kottayam Local & 65.67 & 3.33 & 26.00 & 53.00 & 4.00 & 19.90 & 4.17 & 14.43 & 29.00 & 40.47 & 603.67 & 743.33 & 78.95 & 37.73 & 57.72 \\
\hline A7 & Kuttichal local II & 71.33 & 2.33 & 36.00 & 59.00 & 3.33 & 12.83 & 4.37 & 13.47 & 29.00 & 39.03 & 434.00 & 545.67 & 76.33 & 32.20 & 49.75 \\
\hline A8 & $\begin{array}{l}\text { Kaithamukku } \\
\text { Local }\end{array}$ & 75.00 & 3.33 & 30.33 & 61.67 & 3.67 & 6.47 & 3.23 & 11.37 & 11.33 & 29.00 & 185.67 & 417.33 & 75.25 & 32.03 & 13.97 \\
\hline A9 & Pettah Local & 68.33 & 4.33 & 31.00 & 61.33 & 2.67 & 7.73 & 3.10 & 11.37 & 14.33 & 26.88 & 210.00 & 325.67 & 52.67 & 29.83 & 14.63 \\
\hline A10 & Vellayani local II & 74.33 & 3.67 & 30.67 & 65.67 & 3.33 & 4.60 & 3.73 & 13.90 & 26.67 & 39.51 & 181.33 & 166.67 & 66.33 & 32.80 & 17.76 \\
\hline & $\begin{array}{l}\text { X1-Plant Height } \\
\text { X2-Number of P } \\
\text { X3-Number of L } \\
\text { X4-Days to } 50 \% \\
\text { X5-Number of F } \\
\text { X6-Number of F } \\
\text { X7-Fruit Length } \\
\text { X8-Fruit Girth } \\
\text { X9-Fruit Volume } \\
\text { X10- Fruit Weig } \\
\text { X11-Yield/ Plant } \\
\text { X12-Stomatal Fr } \\
\text { X13-Relative wa } \\
\text { X14-Canopy Ter } \\
\text { X15-Proline con }\end{array}$ & $\begin{array}{l}\text { imary Br } \\
\text { aves/ Pla } \\
\text { flowerin } \\
\text { uits /Clus } \\
\text { uits /Plan } \\
\text { quency } \\
\text { er conten } \\
\text { perature } \\
\text { nt }\end{array}$ & ches/ P & & & & & & & & & & & & & \\
\hline
\end{tabular}


Table.2 Continued

\begin{tabular}{|c|c|c|c|c|c|c|c|c|c|c|c|c|c|c|c|c|}
\hline $\begin{array}{l}\text { Accession } \\
\text { No. }\end{array}$ & $\begin{array}{l}\text { Name of the } \\
\text { accession }\end{array}$ & X1 & $\mathbf{X} 2$ & X3 & $\mathbf{X} 4$ & X5 & X6 & X7 & X8 & X9 & $\mathrm{X} 10$ & X11 & X12 & $\mathrm{X} 13$ & $\mathrm{X} 14$ & X15 \\
\hline A11 & Haripad Local & 67.00 & 3.67 & 21.33 & 3.33 & 3.00 & 5.27 & 3.30 & 12.50 & 21.33 & 29.11 & 161.00 & 345.00 & 54.98 & 32.23 & 14.14 \\
\hline A12 & ArkaAlok & 65.67 & 2.67 & 19.67 & 59.33 & 2.67 & 12.63 & 4.33 & 13.30 & 25.33 & 43.00 & 404.33 & 344.67 & 71.14 & 30.30 & 16.87 \\
\hline A13 & Thrissur Local & 64.33 & 3.00 & 24.00 & 53.33 & 3.33 & 4.77 & 3.37 & 12.40 & 23.67 & 38.48 & 186.67 & 262.67 & 66.85 & 32.33 & 6.03 \\
\hline A14 & ArkaVikas & 71.00 & 2.67 & 32.00 & 66.00 & 4.33 & 4.83 & 4.33 & 14.17 & 29.33 & 45.66 & 140.33 & 335.00 & 65.79 & 29.90 & 12.92 \\
\hline A15 & ArkaSaurabh & 73.00 & 3.00 & 19.00 & 62.67 & 4.00 & 8.37 & 3.23 & 10.23 & 12.33 & 26.09 & 238.33 & 448.00 & 65.68 & 31.07 & 37.86 \\
\hline A16 & ArkaMeghali & 52.67 & 3.00 & 27.33 & 63.33 & 3.67 & 12.50 & 3.63 & 11.33 & 24.33 & 28.69 & 397.33 & 708.35 & 71.25 & 38.53 & 7.00 \\
\hline A17 & Vellayani Vijay & 70.67 & 3.67 & 22.00 & 64.00 & 3.67 & 7.67 & 3.47 & 12.80 & 24.00 & 34.00 & 195.00 & 612.25 & 72.46 & 30.43 & 28.23 \\
\hline A18 & Anagha & 60.00 & 5.00 & 39.67 & 59.67 & 3.33 & 9.67 & 4.23 & 14.47 & 27.00 & 31.34 & 274.60 & 464.33 & 70.90 & 30.87 & 32.97 \\
\hline A19 & Akshay & 77.00 & 4.33 & 33.67 & 58.33 & 3.67 & 10.27 & 3.37 & 12.93 & 21.00 & 26.78 & 281.67 & 423.67 & 68.52 & 30.93 & 15.22 \\
\hline \multirow[t]{3}{*}{ A20 } & Manulekshmi & 66.00 & 4.00 & 24.33 & 61.33 & 2.67 & 7.07 & 3.03 & 11.20 & 20.67 & 31.00 & 177.33 & 216.00 & 63.41 & 29.10 & 2.84 \\
\hline & S.E. & 3.11 & 0.28 & 2.10 & 1.53 & 0.32 & 0.74 & 0.27 & 0.71 & 1.44 & 2.42 & 14.42 & 5.13 & 1.51 & 1.67 & 2.43 \\
\hline & C.D. $5 \%$ & 8.90 & 0.81 & 6.01 & 4.39 & 0.91 & 2.11 & 0.76 & 2.04 & 4.13 & 6.93 & 41.28 & 14.68 & 10.34 & 4.78 & 6.96 \\
\hline
\end{tabular}

X1-Plant Height

X2-Number of Primary Branches/ Plant

X3-Number of Leaves/ Plant

$\mathrm{X} 4-$ Days to $50 \%$ Flowering

X5-Number of Fruits /Cluster

X6-Number of Fruits /Plant

X7-Fruit Length

X8-Fruit Girth

X9-Fruit Volume

X10- Fruit Weight

X11-Yield/ Plant

X12-Stomatal Frequency

X13-Relative water content

X14-Canopy Temperature

X15-Proline content 
Table.3 Genetic parameters

\begin{tabular}{|c|c|c|c|c|c|c|c|c|}
\hline Character & GCV & PCV & ECV & VarianceGenotypical & $\begin{array}{c}\text { Variance } \\
\text { Phenotypical }\end{array}$ & $\begin{array}{c}\text { Variance } \\
\text { Environmental }\end{array}$ & $\begin{array}{l}\text { Heritability } \\
(\%)\end{array}$ & $\begin{array}{l}\text { Gen.Adv.(as } \\
\% \text { of Mean) }\end{array}$ \\
\hline Plant Height & 6.94 & 10.52 & 7.90 & 22.41 & 51.38 & 28.97 & 43.61 & 9.45 \\
\hline $\begin{array}{c}\text { Primary } \\
\text { Branches/ } \\
\text { Plant }\end{array}$ & 22.45 & 26.25 & 13.60 & 0.66 & 0.90 & 0.24 & 73.16 & 39.56 \\
\hline Leaves/ Plant & 22.45 & 25.56 & 12.21 & 44.76 & 58.00 & 13.24 & 77.17 & 40.63 \\
\hline $\begin{array}{c}\text { Days to } 50 \% \\
\text { Flowering }\end{array}$ & 7.36 & 8.6 & 4.44 & 19.34 & 26.39 & 7.05 & 73.29 & 12.98 \\
\hline $\begin{array}{c}\text { Fruits } \\
\text { /Cluster }\end{array}$ & 12.04 & 19.64 & 15.52 & 0.18 & 0.49 & 0.30 & 37.58 & 15.21 \\
\hline Fruits / Plant & 42.93 & 45.13 & 13.91 & 15.54 & 17.18 & 1.63 & 90.5 & 84.14 \\
\hline Fruit Length & 8.97 & 15.5 & 12.64 & 0.11 & 0.32 & 0.21 & 33.52 & 10.7 \\
\hline Fruit Girth & 6.79 & 12.04 & 9.95 & 0.71 & 2.22 & 1.52 & 31.75 & 7.88 \\
\hline Fruit Volume & 30 & 32.02 & 11.20 & 44.83 & 51.07 & 6.24 & 87.78 & 57.9 \\
\hline Fruit Weight & 15.81 & 20.54 & 13.11 & 25.56 & 43.14 & 17.58 & 59.26 & 25.07 \\
\hline Yield/ Plant & 45.58 & 46.44 & 8.91 & 16322.39 & 16946.09 & 623.70 & 96.32 & 92.15 \\
\hline $\begin{array}{c}\text { Stomatal } \\
\text { Frequency }\end{array}$ & 36.14 & 36.2 & 2.05 & 24408.63 & 24487.51 & 78.89 & 99.68 & 74.33 \\
\hline RWC & 9.7 & 12.69 & 8.18 & 55.05 & 94.19 & 39.14 & 58.44 & 15.28 \\
\hline $\begin{array}{c}\text { Canopy } \\
\text { Temperature }\end{array}$ & 5.86 & 10.77 & 9.04 & 3.52 & 11.88 & 8.36 & 29.62 & 6.58 \\
\hline $\begin{array}{l}\text { Proline } \\
\text { Content }\end{array}$ & 66.02 & 68 & 16.30 & 291.30 & 309.05 & 17.75 & 94.26 & 132.03 \\
\hline
\end{tabular}




\section{Int.J.Curr.Microbiol.App.Sci (2018) 7(1): 214-225}

Fig.1 Comparative mean yield performance of twenty tomato genotypes under water stress conditions

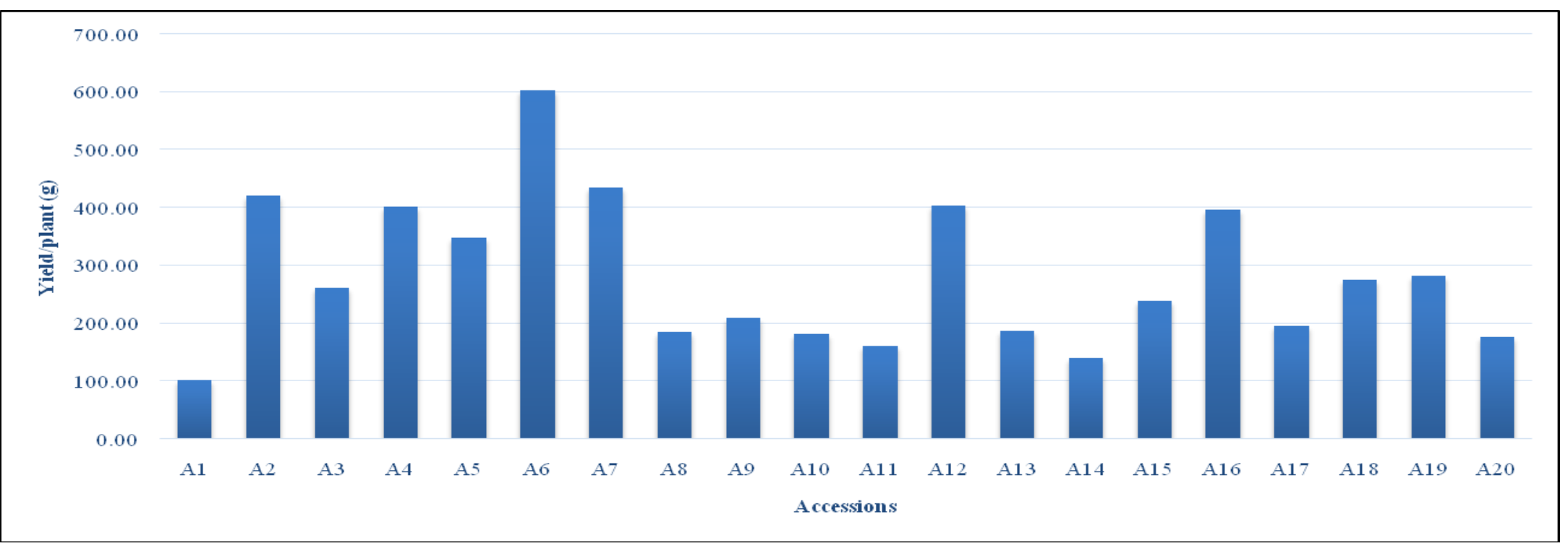

Fig.2 Comparative performance of genotypes based on yield and physiological characters contributing to water stress tolerance

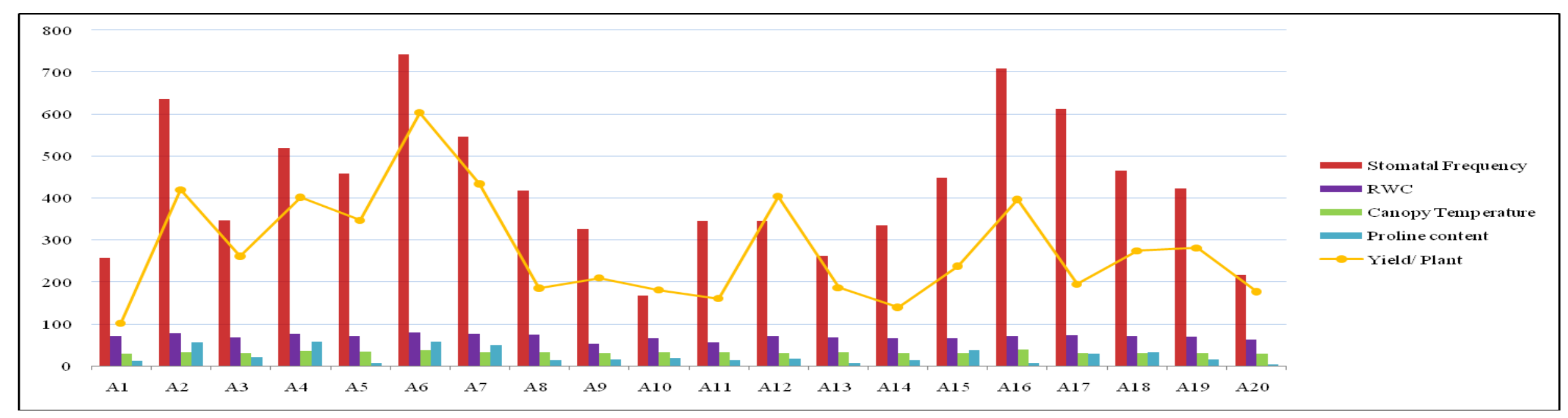


Fig.3 Graph showing genetic parameters, viz., GCV, PCV, ECV, heritability and genetic advance for fifteen characters under study

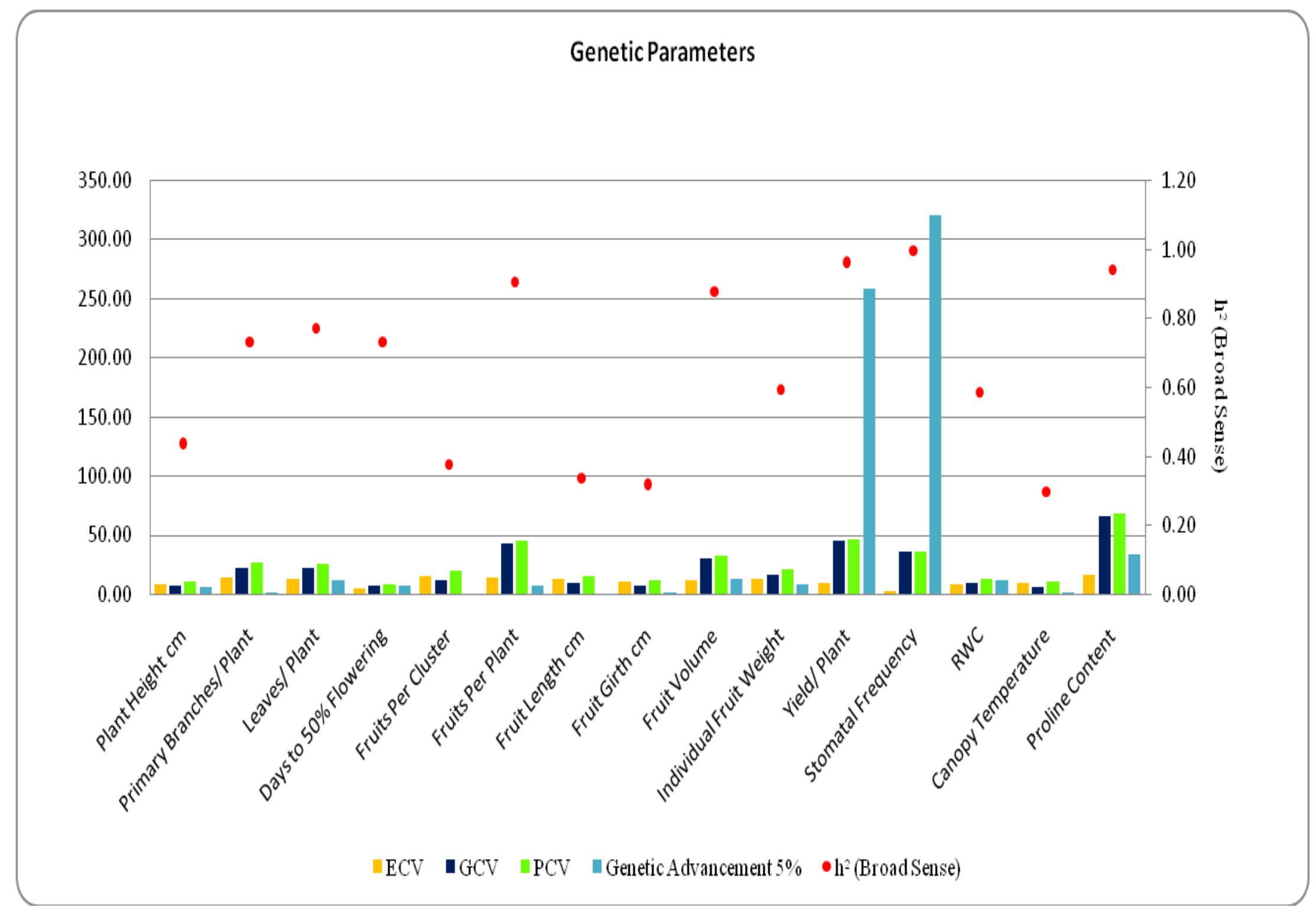


High genotypic variance was observed for most of the characters indicating more contribution of genetic component for the total variation. Therefore, these characters could be considered and exploited for selection purpose. These results were in accordance of the results obtained by Patel et al., (2013), Agrawal et al., (2014) and Khapte and Jansirani (2014).

\section{Phenotypic coefficient of variation}

The phenotypic coefficient of variation (PCV) was found high for proline content of the leaves (68), yield plant ${ }^{-1}$ (46.44), fruits per plant (45.13), stomatal frequency (36.2), fruit volume (32.02), primary branches per plant (26.25), leaves per plant (25.56) and fruit weight(20.54). Moderate phenotypic coefficient of variation was observed for fruits per cluster (19.64), fruit length (15.50), relative water content (12.69), fruit girth (12.04), canopy temperature (10.77) and plant height (10.52). Days to 50\% flowering (8.6) had low phenotypic coefficient of variation. The estimates of phenotypic coefficient of variation (PCV) were higher than genotypic coefficient of variation (GCV) for all the traits studied which is an indicator of additive effect of the environment on the expression of the trait. Similar findings were also reported by Golani et al., (2007), Dar and Sharma (2011), Kaushik et al., (2011), Rani and Anitha (2011) and Chernet et al., (2013).

\section{Heritability and genetic advance}

High heritability was obtained for stomatal frequency $(99.68 \%)$ followed by yield per plant $(96.32 \%)$, proline content of leaves (94.26), number of fruits per plant (90.5), fruit volume $(87.78 \%)$, number of leaves per plant (77.17\%), days to $50 \%$ flowering $(73.29 \%)$ and number of primary branches per plant (73.16\%). Higher broad sense heritability magnitude revealed that greater proportion of the entire variance was due to the greater genotypic variance influenced less by environmental factors therefore having high heritable variations. Moderate heritability was observed for fruit weight $(59.26 \%)$, relative water content $(58.44 \%)$, plant height $(43.61 \%)$, fruits per cluster $(37.58 \%)$, fruit length $(33.52 \%)$ and fruit girth $(31.75 \%)$. Least heritability was observed for canopy temperature (29.62\%) (Fig. 3).

The highest estimate of genetic advance obtained was $132.03 \%$ (proline content) followed by $92.15 \%$ (yield per plant), $84.14 \%$ (fruits per plant), $74.33 \%$ (stomatal frequency), $57.9 \%$ (fruit volume), $40.63 \%$ (number of leaves per plant), 39.56\% (number of primary branches per plant) and $25.07 \%$ (fruit weight). Moderate genetic advance was recorded for relative water content $(15.28 \%)$, fruits per cluster (15.21\%), days to $50 \%$ flowering (12.98\%) and fruit length (10.7\%). Low genetic advance was observed for plant height $(9.45 \%)$, fruit girth $(7.88 \%)$ and canopy temperature $(6.58 \%)$.

High heritability with high estimates of genetic gain was observed for number of primary branches plant $^{-1}$ number of leaves plant $^{-1}$, number of fruits plant ${ }^{-1}$, fruit volume, yield plant $^{-1}$, stomatal frequency and proline content. The results were in accordance with the findings of Rai et al., (2016) in tomato. High heritability coupled with high genetic advance was also reported for plant height, number of fruits plant ${ }^{-1}$ and yield plant ${ }^{-1}$ in tomato by Reddy et al., (2013).

In the present study, heritability estimates were moderate for fruit length. The results were contradictory to that observed by Golani et al., (2007) who reported high estimates of heritability coupled with low GCV and genetic gain for fruit length, which might be attributed to non-additive gene action controlling its expression. Simple selection 
would not be rewarding, but could be improved by development of hybrid varieties or utilization of trangressive segregants in heterosis breeding programme. The present results were in confirmation with the results of Das et al., 1998; Prasad and Rai, 19

The study revealed that accession A6 (Kottayam local) was superior in yield performance under water stress condition followed by the accession A4 (Palakkad Local), accession A2 (Kuttichal Local I) and accession A7 (Kuttichal Local II). The accession A6 (Kottayam local) also recorded the highest relative water content, stomatal frequency and proline content. Accumulation of proline in leaves was found to be an important water stress tolerance mechanism. The results of the study also imply that in order to select high yielding genotypes under water stress conditions, emphasis must be placed on important traits such as number of fruits cluster $^{-1}$, fruit weight, RWC, fruit volume, number of primary branches plant ${ }^{-1}$, proline content and stomatal frequency. The promising genotypes identified in the study can be used in further crop improvement programmes for developing water stress tolerant varieties.

\section{References}

Agrawal, A., Arya, N. and Ahmed, Z. 2014. Genetic variability studies in tomato (Solanum lycopersicum Mill.). Prog. Hortic. 46(2): 50-52.

Basavaraj, N., Shashikanth, Hosamani, R. M., and Patil, B. C. 2010.Genetic variability in tomato (Solanum lycopersicon [Mill]. Wettsd.). Karnataka J. Agric. Sci. 23(3): 536-537.

Bates, L. S., Waldren, R. P., and Teare, I. D. 1973. Rapid determination of proline for water stress studies. Plant Soil.39, 205-207.

Boyer, J.S. 1982. Plant productivity and environment. Sci. 218:443-448.

Burton, G.W. 1952. Proc. $6^{\text {th }}$ Int. Grassl. Cong. 1: 277-283.

Cattivelli, L., Rizza, F., Badeck, F. W., Mazzucotelli, E., Mastrangelo, A. M., Tondelli, A., and Stanca, A. M. 2008. Drought tolerance improvement in crop plants: an integrated view from breeding to genomics. Field Crop Res.105: 1-14.

Cheema, D. and Singh, H. 2005. Studies on genetic variability and heritability for quality traits of tomato (Lycopersicon esculentum Mill.) under heat stress conditions. J. Appl. Hortic. 7(1): 55-57.

Chernet, S., Belew, D. and Abay, F. 2013.Genetic variability and association of characters in tomato (Solanumlycopersicum L.) genotypes in northern Ethiopia. Int. J. Agric. Res. 8(2): 67- 76.

Dar, R.A. and Sharma, J.P. 2011. Genetic variability studies of yield and quality traits in tomato (Solanum lycopersicum L.). Int. J. Plant Breed. Genet. 5(2): 168- 174.

FAO (Food and Agriculture Organization) Database. 2011.

Ghosh, K.P., Islam, A.K.A., Mian, M.A.K., and Hossain, M.M. 2010.Variability and character association in F2 segregating population of different commercial hybrids of tomato (Solanum lycopersicum Mill). J. Appl. Sci. Environ. Manag. 14(2): 91- 95.

Golani, I.J., Mehta, D.R., Purohit, V.L., Pandya, H.M., and Kanzariya, M.V. 2007. Genetic variability, correlation and Path coefficient studies in tomato. Indian J. Agric. Res.41 (2): 146 - 149.

Haydar, A., Mandal, M. A., Ahmed, M. B., Hannan, M. M. and Karim, R. 2007.Studies on genetic variability and interrelationship among the different traits in tomato (Lycopersicon esculentum Mill.). J. Sci. Res. 2: 139- 
142.

Johnson, H.W., Robinson, H.F. and Comstock, R.E. 1955. Estimation of genetic and environmental variability in soybeans. Agron. J. 47:314-318.

Kaushik, S. K., Tomar, D. S., and Dixit, A. K. 2011. Genetics of fruit yield and it's contributing characters in tomato (Solanum lycopersicon). J. Agri. Biot. Sustainable Development. 3(10):209 213.

Mehta, N. and Asati, B. S. 2008.Genetic relationship of growth and development traits with fruit yield in tomato (Lycopersicon esculentum Mill.). Karnataka J. Agric. Sci. 21: 92-96.

Narolia, R. K., Reddy, R. V. S. K. and Sujatha, M. 2012. Genetic architecture of yield and quality in tomato (Solanum lycopersicon). Agric. Sci. Digest. 32(4):
281-285.

Panse, V. G. and Sukhatme, P. V. 1985.Statistical Methods for Agricultural Workers (2nd Edn.), Indian Council of Agricultural Research, New Delhi.p. 381.

Prasad, V.S.R.K. and Rai, M. 1999. Genetic variation, component association and direct and indirect selections in some exotic tomato germplasm. Indian $J$. Hort.56: 262-266

Rani, K. and Anitha, V. 2011.Studies on Variability, Heritability and Genetic Advance in Tomato (Lycopersicon esculentum M.). Int. J. Bio-Resour. Stress Manag. 2 (4): 382-385.

Rick, C. M. 1969. Origin of cultivated tomato, current status of the problem. Abstract. XI International Botanical Congress. pp180.

\section{How to cite this article:}

Namitha Elizabeth, Beena Thomas and Thouseem, N. 2018. Evaluation of Tomato (Solanum lycopersicum L.) Genotypes under Water Stress Based on Yield and Physiological Parameters. Int.J.Curr.Microbiol.App.Sci. 7(01): 214-225. doi: https://doi.org/10.20546/ijcmas.2018.701.024 